DOI: https://doi.org/10.47405/mjssh.v6i9.1023

\begin{tabular}{|c|c|}
\hline 4 & Malaysian Journal of Social Sciences and Humanities (MJSSH) \\
\hline $\begin{array}{l}\text { Malaysian Juoural of } \\
\text { Social ccciecces and }\end{array}$ & Volume 6, Issue 9, September 2021 \\
\hline (MJ-sSH) & e-ISSN : 2504-8562 \\
\hline & $\begin{array}{l}\text { Journal home page: } \\
\text { www.msocialsciences.com }\end{array}$ \\
\hline
\end{tabular}

\title{
Penglibatan Ibu bapa dan Efikasi Kendiri Murid Sekolah Menengah dalam Membuat Keputusan Kerjaya
}

\author{
Fam Mei Mei'1, Faridah Mydin Kutty'1, Norasmah Othman ${ }^{1}$ \\ ${ }^{1}$ Fakulti Pendidikan, Universiti Kebangsaan Malaysia (UKM) \\ Correspondence: Fam Mei Mei (p98386@siswa.ukm.edu.my)
}

\begin{abstract}
Abstrak
Pemilihan kerjaya yang bertepatan dengan bakat, minat, personaliti serta pencapaian akademik adalah aspek penting dalam kehidupan seseorang murid. Dalam hal ini, penglibatan ibu bapa dan efikasi kendiri memainkan peranan penting dalam membantu murid membuat keputusan kerjaya. Melihat daripada perspektif murid di sekolah menengah swasta, kajian ini bertujuan untuk melihat tahap penglibatan ibu bapa dan tahap efikasi kendiri murid dalam membuat keputusan kerjaya. Seterusnya, kajian ini menentukan hubungan antara penglibatan ibu bapa dan efikasi kendiri pelajar ke atas keputusan kerjaya. Reka bentuk kajian kuantitatif berbentuk tinjauan dan kaedah persampelan rawak mudah digunakan untuk memilih 306 murid sekolah menengah swasta tingkatan empat/gred 10 dan tingkatan lima/gred 11. Soal selidik dalam bentuk google form yang ditadbir secara atas talian digunakan sebagai kaedah pengumpulan data. Data dianalisis secara deskriptif dan inferensi dengan menggunakan SPSS versi 25.0. Hasil analisis deskriptif menunjukkan nilai min bagi tahap penglibatan ibu bapa mengikut subskala bantuan instrumental dan sokongan emosi adalah tinggi $(\mathrm{M}=3.712$, $\mathrm{SP}=0.648$ ). Di samping itu, analisis deskriptif terhadap nilai min keseluruhan bagi tahap efikasi kendiri murid dalam membuat keputusan kerjaya juga adalah tinggi $(\mathrm{M}=3.711, \mathrm{SP}=0.514)$. Dapatan kedua-dua analisis menunjukkan kebanyakan murid sekolah menengah swasta memperoleh skor tahap penglibatan ibu bapa dan efikasi kendiri yang tinggi. Hasil analisis Kolerasi Pearson menggambarkan hubungan yang kuat dan positif $(r=0.682)$ di antara penglibatan ibu bapa dan efikasi kendiri murid dalam membuat keputusan kerjaya. Secara kesimpulannya, kajian ini jelas menunjukkan bahawa penglibatan ibu bapa dari segi bantuan instrumental dan sokongan emosi merupakan peramal efikasi kendiri seseorang murid dalam membuat keputusan kerjaya. Implikasi dapatan kajian ini dapat menjadi rujukan kepada ibu bapa supaya mempunyai pengetahuan yang lebih meluas tentang peluang kerjaya serta haluan kerjaya anak-anak mereka.
\end{abstract}

Kata kunci: penglibatan ibu bapa, efikasi kendiri, membuat keputusan kerjaya, murid menengah, sekolah swasta

\section{Parental Involvement and Self -Efficacy of Secondary School Students in Career Decision Making}

\begin{abstract}
Choosing a career that coincides with talents, interests, personalities and academic achievement is an important aspect of a student's life. In this regard, parental involvement and self-efficacy play an important role in helping students make career decisions. Seen from the perspective of students in private secondary schools, this study aims to look at the level of parental involvement and the level
\end{abstract}


of self-efficacy of students in career decision making. Next, this study determined the relationship between parental involvement and students' self -efficacy on career decisions. The survey-type quantitative study design and simple random sampling method were used to select 306 private secondary school students form four/ grade 10 and form five/ grade 11. A questionnaire in the form of google form administered online was used as data collection method. Data were analyzed descriptively and inferentially using SPSS version 25.0. The results of descriptive analysis showed that the mean value for the level of parental involvement according to the subscale of instrumental assistance and emotional support was high $(\mathrm{M}=3.712, \mathrm{SP}=0.648)$. In addition, the descriptive analysis of the overall mean value of the level of students' self -efficacy in making career decisions was also high $(\mathrm{M}=3.711, \mathrm{SP}=0.514)$. The findings of both analyzes showed that most private secondary school students obtained high scores of parental involvement and self-efficacy levels. The results of Pearson Correlation analysis illustrate a strong and positive relationship $(r=0.682)$ between parental involvement and student self -efficacy in career decision making. In conclusion, this study clearly shows that parental involvement in terms of instrumental help and emotional support is a predictor of a student's self -efficacy in career decision making. The implications of the findings of this study can be a reference for parents to have a broader knowledge of career opportunities and career paths of their children.

Keywords: parental involvement, self-efficacy, making career decision, private secondary students

\section{Pengenalan}

Membuat keputusan kerjaya merupakan perancangan penting dalam fasa kehidupan seseorang murid. Kerjaya idaman menjadikan murid lebih konsisten dalam mengenal pasti bentuk pekerjaan yang sesuai supaya murid tidak terperangkap dengan kerjaya yang tidak diminati (Zakaria, 2020; Salem et al., 2018). Di peringkat sekolah menengah, pelbagai program kerjaya telah diadakan bagi mendedahkan murid dengan maklumat kerjaya, kriteria kelayakan serta syarat-syarat yang perlu dipenuhi. Kriteria tersebut adalah seperti kelayakan akademik, latihan atau pengalaman, deskripsi tugas, faedah dan kemudahan serta peluang kenaikan pangkat dan penghargaan (Izwan et al., 2016; Fabio et al., 2013). Pengetahuan ini perlu awal didedahkan kepada murid sebab berdasarkan kajian oleh Samad et al. (2019) dan Bullock et al. (2014) masih terdapat sebilangan besar murid yang keliru dan mempunyai masalah dalam membuat keputusan pilihan kerjaya.

Kajian oleh Zairoslawani (2014) melaporkan bahawa membuat keputusan kerjaya bukanlah suatu perkara yang mudah dan senang bagi seseorang murid. Lazimnya, permasalahan ini boleh dipengaruhi oleh tahap keyakinan atau efikasi kendiri murid (Normah, 2020; Tasriff et al., 2016). Ini kerana, murid yang mempunyai tahap kepercayaan yang tinggi terhadap keupayaan diri sendiri terbukti mendorong kepada pemilihan kerjaya yang sesuai pada masa hadapan (Rohaty et al., 2011). Namun, murid yang efikasi kendirinya lemah mempunyai keyakinan rendah dan sukar untuk membuat pilihan kerjaya diri sendiri (Kristin, 2014; Sidiropouou et al., 2012).

Selain pengaruh keperibadian murid, penglibatan ibu bapa didapati mempengaruhi pengetahuan, kepercayaan dan kebolehan murid dalam pemilihan kerjaya (Aisyah, 2018; Guay et al., 2003). Hal ini demikian kerana aspek-aspek seperti perbincangan, gaya asuhan dan komunikasi dengan anak- anak akan mencorakkan cara hidup serta cara mereka membuat keputusan pada masa hadapan (Zulkifli et al., 2011; Noraini, 2001). Kajian Anuar dan Norhaidawati (2016) telah membuktikan bahawa sokongan dan kasih sayang yang kurang diberikan oleh ibu bapa kepada pelajar disebabkan oleh perceraian, masalah keluarga serta kesibukan ibu bapa akan menjadi penghalang terhadap anak-anak dalam membuat keputusan kerjaya.

Kajian berhubung dengan pemilihan kerjaya dalam konteks Malaysia lebih berfokus kepada sekolahsekolah awam dan masih kurang kajian dijalankan di sekolah swasta yang terdiri daripada golongan ibu bapa yang mempunyai tahap pendidikan dan pendapatan yang tinggi. Justeru, kajian ini dijalankan bagi meneroka faktor penglibatan ibu bapa dan efikasi kendiri dalam membuat keputusan terhadap kerjaya 
dalam kalangan murid sekolah menengah swasta. Oleh demikian, terdapat tiga objektif yang pengkaji ingin tercapai dalam kajian ini antaranya;

i. Mengenal pasti tahap penglibatan ibu bapa terhadap murid sekolah menengah swasta dalam membuat keputusan kerjaya.

ii. Mengenal pasti tahap efikasi kendiri murid sekolah menengah swasta dalam membuat keputusan kerjaya.

iii. Mengenal pasti hubungan antara penglibatan ibu bapa terhadap efikasi kendiri dalam membuat keputusan kerjaya di kalangan murid menengah swasta.

\section{Sorotan Literatur}

\section{Pemilihan Kerjaya}

Dalam kehidupan setiap individu, kerjaya dilihat sebagai suatu aktiviti kerjaya yang berterusan dan kesinambungan yang dapat memberi jaminan untuk meneruskan kehidupan. Menurut Norasmah (2011), kerjaya dilihat sebagai agenda yang penting dan berkait rapat dengan perkembangan individu dan kesejahteraan hidup. Oleh demikian, pemilihan kerjaya yang betul adalah penting kerana ia akan menggambarkan masa depan individu. Seseorang individu dapat memperoleh manfaat dalam kehidupannya, lebih bermotivasi terhadap kerjayanya dan memperoleh kejayaan di masa hadapan apabila memilih kerjaya yang tepat (Josephine, 2016). Menurut Khuzaimah (2019) apabila seseorang individu memilih kerjaya yang tidak sesuai menyebabkan seseorang menghadapi tekanan kerja, kebosanan dan sering membuat pertukaran kerja. Lantaran itu, penelitian tidak boleh diabaikan semasa pemilihan kerjaya kerana tindakan tersebut memberi jangka masa yang panjang terhadap masa depan seseorang (Noraziyati et al., 2018).

Zairolawanee (2014) menyatakan pemilihan kerjaya telah menjadi satu isu perbahasan terutama golongan murid sekolah menengah, pelajar politeknik, pusat pengajian tinggi awam atau swasta kerana masih terdapat banyak murid yang tidak tetap dengan pendirian mereka selepas tamat persekolahan. Ini menyebabkan mereka berkali-kali bertukar kerjaya dan akhirnya terperangkap dengan kerjaya yang tidak diminati. Lantaran itu, isu yang menyebabkan pemilihan kerjaya yang tidak sesuai adalah murid kurang berpengetahuan tentang kerjaya apabila persekolahan berakhir (Mansor, 2013). Tambahan pula, pelajar cenderung kepada bidang kerjaya yang diingini supaya kepuasan kerjaya dicapai dan mereka akan kekal lebih lama dalam kerjaya yang dipilih (Sidek, 2006). Seperti mana dalam kajian Noraziyati (2018) mendapati kepentingan bagi murid membuat pemilihan kerjaya yang bersesuaian yang bakal menentukan masa depan dan gaya kehidupan yang diingini.

Oleh itu, adalahlah penting kepada setiap murid untuk menentukan bidang yang mereka ingin ceburi sebelum melangkah ke alam sekerajaan. Justeru itu, aspek perancangan dan pemilihan kerjaya merupakan hal yang perlu dititikberatkan kerana ia akan menentukan gaya hidup masa depan seseorang (Fatihah, 2021; Fadilla, 2020). Tambahan lagi, susunan maklumat yang teratur dapat membantu murid lebih memahami diri, mempelajari dunia kerjaya dan mendapatkan pengalaman yang dapat membantu mereka membuat keputusan kerjaya dengan tepat (Sidek Mohd, 2012).

\section{Efikasi Kendiri Terhadap Pemilihan Kerjaya}

Bandura (1986) mendefinisikan efikasi kendiri sebagai keyakinan individu terhadap kemampuannya untuk melaksanakan tindakan atau tugas yang diperlukan untuk mencapai kejayaan. Efikasi kendiri dianggap sebagai asas dan indikator berpengaruh untuk mengendalikan kawalan ke atas tingkah laku seseorang, pemikiran, pembelajaran, dan proses-proses tertentu (Chong, 2007). Oleh demikian, efikasi kendiri dilihat sebagai satu faktor yang dapat mempengaruhi keputusan kerjaya seseorang. Dalam teori kerjaya kognitif sosial (TKKS) oleh Lent, Brown dan Hackett $(1994,2000)$ yang berasal daripada ideaidea asas teori kognitif sosial menjelaskan efikasi kendiri dalam membuat keputusan kerjaya merupakan konstruk teras dalam pengembangan kerjaya. Melalui teori ini, proses membuat keputusan kerjaya dilihat sebagai proses yang berkaitan dengan pembentukan matlamat, membuat pilihan, dan pencapaian prestasi berlandaskan kepada tahap efikasi kendiri seseorang (Lent et al., 2000). 
Berdasarkan kajian Betz dan Hackett (1986), kecenderungan memilih kerjaya adalah dipengaruhi oleh tahap efikasi kendiri individu. Ini juga dilaporkan dalam kajian Aisyah (2018), terdapat hubungan yang positif dan signifikan di antara efikasi kendiri dengan keputusan kerjaya individu dalam kalangan murid tingkatan empat. Hasil kajian Hashim dan Ishak (2007) pula menunjukkan majoriti pelajar di IPTA yang mempunyai efikasi kendiri yang tinggi mampu merancang walaupun sukar serta tidak mengalah walaupun menghadapi halangan dalam membuat keputusan kerjaya. Secara jelasnya semakin tinggi tahap efikasi kendiri seseorang murid itu maka semakin tinggi tahap kepercayaan mereka.

Bandura (1986) menyatakan efikasi kendiri mempengaruhi prestasi dengan meningkatkan usaha dan kecekalan. Seperti mana dalam kajian Zainuddin (2021) melaporkan bahawa murid lebih percaya dapat melakukan sesuatu tugas dengan baik berbanding dengan murid yang mempunyai tahap efikasi yang rendah. Sehubungan dengan ini, hasil kajian Hashim dan Ishak (2007) juga menunjukkan majoriti murid yang mempunyai tahap efikasi kendiri yang tinggi, yakin bahawa mereka dapat melakukan suatu tugas dengan cekap walaupun sukar, tidak mengalah, dan berupaya untuk merancang. Kajian ini telah membuktikan efikasi kendiri bukan dinilai dari kemahiran seseorang sahaja tetapi juga terhadap keyakinan mereka dalam melaksanakan sesuatu perkara. Individu yang mempunyai efikasi kendiri yang tinggi akan menganalisis sesuatu situasi secara objektif termasuk kejayaan dan kegagalan dan dapat menjelaskan kejayaan dan kegagalan mereka dengan refleksi diri. Walaupun menghadapi halangan atau cabaran, individu yang mempunyai tahap efikasi kendiri yang tinggi mampu mengekalkan sikap positif dan mengambil inisiatif.

\section{Penglibatan ibu bapa}

Ibu bapa merupakan suri teladan kepada anak kerana mereka merupakan orang yang terdekat dan berpengaruh kepada keputusan kerjaya anak (Shazia et al., 2019; Bright et al., 2005). Sebagai ibu bapa, harapan mereka untuk melihat anak-anak mencapai kejayaan dalam kehidupan akan membawa kegembiraan dan kebanggaan kepada keluarga. Namun, proses membuat keputusan kerjaya menjadi lebih sukar bagi anak tanpa bimbingan orang dewasa yang memahami selok-belok proses keputusan kerjaya (Watkinson \& Hersi, 2014). Ini adalah kerana pada peringkat ini, isu yang dihadapi oleh murid kerana mereka masih kurang pengalaman dan belum matang untuk membuat keputusan kerjaya dan masih memerlukan bantuan dan nasihat ibu bapa. Menurut Su'adah et al. (2013), dorongan dan sokongan daripada ibu bapa merupakan faktor kejayaan anak-anak. Oleh demikian, faktor ini penting kepada anak- supaya mereka menjadi lebih berdikari dan cekal (Azizi Yahya, 2016).

Menurut Gosman (2020), anak-anak memerlukan sokongan moral daripada ibu bapa seperti ucapan tahniah, pelukan dan hadiah penghargaan yang dapat menjadi pembakar semangat kepada mereka untuk terus meraih kejayaan dalam kehidupan. Malah, kecenderungan penglibatan ibu bapa dari aspek sokongan emosi juga dapat memberi impak yang positif kepada perkembangan anak-anak ke arah yang lebih positif. Secara terperinci, sokongan emosi seperti berkomunikasi, perbincangan dan pujian kepada anak-anak ke atas kejayaan yang diraih di sekolah atau di luar sekolah dianggap penting alam proses perkembangan anak-anak. Ini selari dengan dapatan kajian oleh Elizaberth et al. (2016) mendapati pelajar memerlukan sokongan emosi daripada ibu bapa kerana mereka memerlukan perhatian orang-orang yang signifikan dengan dirinya. Lazimnya, komunikasi yang berkesan di antara ibu bapa dengan anak-anak dapat membentuk sokongan emosi yang baik justeru membantu anak lebih cekal dalam menghadapi sebarang rintangan semasa proses membuat keputusan kerjaya.

Selain daripada sokongan dari segi emosi dan moral, status sosioekonomi juga boleh mempengaruhi keputusan kerjaya murid. Ini adalah kerana status sosioekonomi keluarga biasanya mencerminkan tahap pendidikan dan pekerjaan ibu bapa dan status kewangan. Oleh demikian, status sosioekonomi keluarga mempunyai pengaruh besar terhadap keputusan kerjaya pelajar dan pencapaian dalam prestasi pekerjaan (Rojewski, 1997; Whiston \& Keller, 2004). Ibu bapa daripada keluarga status sosioekonomi yang lebih tinggi lebih cenderung menyokong dan menggalakkan penerokaan kerjaya anak-anak, memberi maklumat kerjaya, sumber kerjaya untuk perancangan kerjaya dan membuat keputusan kerjaya (Hsieh \& Huang, 2014). Murid daripada golongan keluarga yang berstatus sosioekonomi yang lebih tinggi sering menetapkan jangkaan tahap pencapaian pendidikan yang lebih tinggi dan bercitacita untuk pekerjaan yang lebih berprestasi (Rojewski \& Kim, 2003). 


\section{Metod Kajian}

Reka bentuk kajian ini adalah berbentuk kuantitatif dengan menggunakan pendekatan berbentuk tinjauan. Pengkaji menggunakan soal selidik sebagai instrumen pengumpulan data. Menurut Cooper dan Schindler (2003) kelebihan menggunakan kaedah ini ialah dapat mencapai responden yang sukar dihubungi, kos yang rendah, dapat meliputi kawasan yang jauh dan memberi ruang masa kepada responden untuk berfikir sebelum menjawab soalan.

Populasi kajian ini tertumpu kepada pelajar tingkatan empat dan lima daripada sekolah swasta di daerah Petaling Jaya iaitu seramai 725 orang (Jabatan Pendidikan Swasta, 2021). Pendekatan kaedah persampelan rawak telah digunakan dengan menetapkan saiz sampel sebanyak 248 orang bagi kajian ini dengan merujuk kepada jadual penetapan oleh Krejcie dan Morgan (2013). Sejumlah 350 borang soal selidik telah diedarkan atas talian kepada murid tingkatan empat/gred 10 dan tingkatan lima/gred 5 sekolah menengah swasta dan hanya 306 responden yang terdiri daripada murid telah menjawab google form yang telah diedarkan.

Soal selidik ini terdapat tiga bahagian iaitu Bahagian A adalah bertujuan untuk mendapatkan maklumat diri yang berkaitan dengan jantina, umur, tingkatan dan pendapatan ibu bapa. Bahagian B, sebaliknya, mengandungi 14 item yang diadopsi dari instrumen Career Related Parent Support Scale (CRPSS) yang dikembangkan oleh Tuner et al. (2003) dan diperoleh daripada kajian Bazlan (2011). Daripada 14 item tersebut, 7 item adalah untuk mendapatkan maklumat mengenai tahap penglibatan ibu bapa dari aspek bantuan instrumental dan 7 item lagi adalah untuk melihat tahap sokongan emosi untuk keputusan kerjaya di kalangan pelajar. Soal selidik di bahagian ini menggunakan skala likert lima mata iaitu bermula dengan $1=$ sangat tidak setuju, hingga $5=$ sangat setuju. Bahagian $C$ pula mengandungi 25 item yang adaptasi dari instrumen Career Decision-Making Self-Efficacy (CDMSE) oleh Betz et al. (1996) bagi mengukur tahap efikasi kendiri pelajar terhadap keputusan kerjaya dalam kalangan pelajar. Soal selidik di bahagian ini juga menggunakan skala likert lima poin iaitu bermula dengan $1=$ sangat tidak berkeyakinan, hingga 5 = sangat berkeyakinan.

Kesahan kandungan dalam instrumen soal selidik ini adalah melalui penilai pakar (Creswell 2012). Pemilihan bilangan pakar adalah berdasarkan kepada Lynn (1986) menyatakan bahawa panel pakar harus terdiri daripada 3 hingga 20 orang yang terlibat dalam bidang yang sama dan mempunyai kepakaran dalam pengembangan instrumen. Dalam kajian ini, pengkaji telah memilih dua orang pakar yang terdiri daripada pensyarah kanan universiti di Fakulti Pendidikan, UKM.

Kajian rintis dijalankan juga untuk menguji kesahan dan kebolehpercayaan soal selidik. Hasil ujian Cronbach Alpha menunjukkan bahawa indeks kebolehpercayaan berdasarkan pemboleh ubahpemboleh ubah iaitu penglibatan ibu bapa dan efikasi kendiri keputusan kerjaya seperti yang digambarkan dalam Jadual 1. Menurut Pallant (2001) nilai Alpha Cronbach 0.7 ke atas adalah baik. Oleh demikian, hasil kajian rintis menunjukkan kesemua item mempunyai nilai kebolehpercayaan yang baik sekali gus menjadikan semua indikator yang diguna bagi mengukur pemboleh ubah berjaya mencapai nilai kebolehpercayaan konsistensi dalaman yang ditetapkan (Sekaran, 2013). Analisis kesahan yang telah dijalankan pula menunjukkan nilai korelasi antara skor item dengan jumlah skor ialah antara 0.26 hingga 0.810 .

Jadual 1: Keputusan kajian rintis mengikut pemboleh ubah

\begin{tabular}{lccc}
\hline Pemboleh ubah & Bilangan Item & Nilai Alpha \\
\hline Penglibatan Ibu bapa & 14 & 0.763 & \\
Efikasi Kendiri & 25 & 0.960 & \\
\hline
\end{tabular}

Dapatan yang diperoleh dalam kajian ini dianalisis dengan menggunakan SPSS versi 25.0. Dua jenis statistik yang berbeza digunakan untuk menganalisis data iaitu statistik deskriptif dan statistik inferensi. Pengkaji menggunakan analisis statistik deskriptif bagi melihat tahap penglibatan ibu bapa yang mengandungi dua subskala iaitu bantuan instrumental dan sokongan emosi dan tahap efikasi 
DOI: https://doi.org/10.47405/mjssh.v6i9.1023

kendiri dalam kalangan pelajar. Hasil kajian analisis deskriptif diinterpretasikan dengan merujuk kepada jadual penentuan tahap skor min sepertimana yang ditunjukkan dalam Jadual 2.

Jadual 2: Interpretasi tahap skor min

\begin{tabular}{cc}
\hline Skor Min & Tahap \\
\hline 1.0 hingga 2.33 & Rendah \\
2.34 hingga 3.66 & Sederhana \\
3.67 hingga 5.00 & Tinggi \\
\hline
\end{tabular}

Sumber : Adaptasi daripada Sekaran (1992)

Ujian lanjutan dilaksanakan untuk melihat hubungan antara penglibatan ibu bapa terhadap efikasi kendiri dalam membuat keputusan kerjaya kalangan pelajar menengah swasta. Bagi tujuan ini, ujian korelasi Pearson digunakan untuk melihat kekuatan hubungan di antara kedua-dua pemboleh ubah. Hasil dapatan korelasi diinterpretasikan oleh pengkaji dengan merujuk kepada Jadual Pekali Korelasi dalam Jadual 3.

Jadual 3: Interpretasi Kekuatan Pekali Korelasi

\begin{tabular}{cc}
\hline Saiz pekali & Kekuatan korelasi \\
\hline \pm .81 hingga 1.00 & Sangat kuat \\
\pm .51 hingga .80 & Kuat \\
\pm .31 hingga .50 & Sederhana \\
\pm .21 hingga .30 & Lemah \\
\pm .01 hingga .20 & Sangat Lemah \\
\hline
\end{tabular}

Sumber : Adaptasi daripada Cohen, Manion dan Morrison (2007)

\section{Hasil Kajian}

\section{Analisis Demografi Responden}

Jadual 4 menunjukkan dapatan data demografi responden berkaitan dengan jantina, tingkatan/gred, kaum dan jumlah pendapatan ibu bapa. Jumlah keseluruhan responden adalah seramai 306 orang. Dapatan kajian menunjukkan taburan responden perempuan adalah seramai 161 orang (53\%) dan lebih ramai berbanding taburan responden lelaki seramai 145 orang (47\%). Dalam kajian ini, taburan responden daripada tingkatan lima/gred 11 lebih banyak iaitu seramai 181 orang (59.2\%) berbanding taburan responden daripada tingkatan empat/gred 10 seramai 125 orang (40.8\%). Seterusnya, taburan responden bagi bangsa Cina adalah paling ramai iaitu seramai 135 orang $(44.1 \%)$ diikuti dengan taburan repsonden bagi bangsa India seramai 196 orang (34.6\%), bangsa Melayu seramai 45 orang (14.7\%) dan bangsa lain-lain seramai 20 orang (6.6\%). Dalam kajian ini juga paling ramai responden daripada golongan jumlah pendapatan ibu bapa RM 5001 hingga RM10 000 iaitu seramai 150 orang $(49 \%)$.

Jadual 4: Demografi Responden $(\mathrm{n}=306$ )

\begin{tabular}{cccc}
\hline \multicolumn{1}{c}{ Maklumat Demografi } & Frekuensi & Peratus (\%) \\
\hline Jantina & Lelaki & 145 & 47.0 \\
& Perempuan & 161 & 53.0 \\
Tingkatan/ & Empat/ Gred 10 & 125 & 40.8 \\
Gred & Lima/ Gred 11 & 181 & 59.2
\end{tabular}




$\begin{array}{cccc}\text { Kaum } & \text { Melayu } & 45 & 14.7 \\ & \text { Cina } & 135 & 44.1 \\ & \text { India } & 106 & 34.6 \\ & \text { Lain-lain } & 20 & 6.6 \\ \text { Jumlah } & & 35 & 11.4 \\ \text { Pendapatan } & \text { RM 5 000 } & 150 & 49.0 \\ \text { Ibu bapa } & \text { S001 - RM 10000 } & 121 & 39.6\end{array}$

\section{Tahap Penglibatan Ibu Bapa Terhadap Murid Dalam Membuat Keputusan Kerjaya}

Dapatan kajian ini adalah menjawab objektif kajian pertama iaitu mengenal pasti tahap penglibatan ibu bapa terhadap murid sekolah menengah swasta dalam membuat keputusan kerjaya. Penglibatan ibu bapa dalam kajian ini ditinjau melalui dua subskala iaitu bantuan instrumental dan sokongan emosi. Jadual 5 menunjukkan analisis deskriptif terhadap nilai min keseluruhan bagi subskala bantuan instrumental $(\mathrm{M}=3.856, \mathrm{SP}=0.535)$ dan berada pada tahap yang tinggi. Dapatan kajian menunjukkan bahawa ibu bapa cenderung melibatkan diri terhadap anak-anak dengan memberi bantuan instrumental seperti memberi penghargaan kepada anak-anak sekiranya mereka memperoleh pencapaian yang baik dalam akademik, membantu membuat keputusan dalam pemilihan jurusan serta membantu mendapatkan maklumat kepada anak-anak untuk mengikuti kursus berkaitan dengan kerjaya yang diminati.

Seterusnya, Jadual 5 menunjukkan analisis deskriptif terhadap nilai min keseluruhan bagi bagi subskala sokongan emosi $(\mathrm{M}=3.705, \mathrm{SP}=0.835)$ pada tahap tinggi. Ini menyatakan ibu bapa cenderung memberi sokongan emosi kepada anak-anak seperti berbincang apabila mereka risau tentang kerjaya pada masa hadapan, memberitahu perkara-perkara yang menggembirakan apabila anak-anak mempelajari sesuatu yang boleh gunakan ketika bekerja serta memberitahu tentang keseronokan dalam bidang pekerjaan yang bakal diceburi oleh mereka. Sokongan emosi yang yang diberikan oleh ibu bapa dapat membantu anak-anak ke arah perkembangan emosi yang positif.

Secara keseluruhannya, analisis deskriptif menunjukkan tahap penglibatan ibu bapa dari segi aspek bantuan instrumental dan sokongan emosi terhadap pelajar $(\mathrm{M}=3.712, \mathrm{SP}=0.648)$ adalah tinggi.

Jadual 5: Interpretasi bagi Tahap Penglibatan Ibu Bapa Terhadap Murid

Dalam Membuat Keputusan Kerjaya

\begin{tabular}{lcccc}
\hline Subskala & $\begin{array}{c}\text { Bilangan } \\
\text { Item }\end{array}$ & Nilai Min & $\begin{array}{c}\text { Sisihan } \\
\text { piawai }\end{array}$ & Interpretasi \\
\hline Bantuan Instrumental & 7 & 3.856 & 0.535 & Tinggi \\
Sokongan Emosi & 7 & 3.705 & 0.835 & Tinggi \\
Keseluruhan & & 3.712 & 0.648 & Tinggi \\
\hline
\end{tabular}

\section{Tahap Efikasi Kendiri Murid Dalam Membuat Keputusan Kerjaya}

Dapatan kajian ini adalah menjawab objektif kedua iaitu mengenal pasti tahap efikasi kendiri murid sekolah menengah swasta dalam membuat keputusan kerjaya. Jadual 6 menunjukkan analisis deskriptif terhadap nilai min keseluruhan bagi tahap efikasi kendiri murid dalam membuat keputusan kerjaya adalah tinggi $(\mathrm{M}=3.711, \mathrm{SP}=0.514)$. Hal demikian menunjukkan murid sekolah menengah swasta cenderung menentukan jenis gaya hidup yang diingini, merancang matlamat kerjaya, menentukan langkah yang perlu diambil untuk mencapai kejayaan dalam kursus pengajian serta yakin bagi membuat keputusan kerjaya dan tidak menyesal. Secara keseluruhannya, murid menengah swasta sangat yakin terhadap kemampuan mereka dalam merancang, memilih matlamat, menyelesaikan masalah, mendapatkan maklumat kerjaya dan penilaian kendiri. 
Jadual 6: Interpretasi bagi Tahap Efikasi Kendiri Murid Dalam Membuat Keputusan Kerjaya

\begin{tabular}{lcccc}
\hline Pemboleh ubah & $\begin{array}{c}\text { Bilangan } \\
\text { Item }\end{array}$ & Nilai min & $\begin{array}{l}\text { Sisihan } \\
\text { piawai }\end{array}$ & Interpretasi \\
\hline Efikasi Kendiri & 25 & 3.711 & 0.514 & Tinggi \\
\hline
\end{tabular}

\section{Hubungan di Antara Penglibatan Ibu Bapa Dan Efikasi Kendiri Membuat Keputusan Kerjaya Dalam Kalangan Murid Menengah Swasta}

Jadual 7 menunjukkan dapatan kajian terhadap analisis korelasi Pearson. Dapatan kajian ini menunjukkan nilai korelasi di antara penglibatan ibu bapa dan efikasi kendiri adalah bersamaan dengan nilai $\mathrm{r}=0.682$ pada paras $=.000, \mathrm{p}<0.05$. Berpandukan kepada indeks korelasi yang dicadangkan oleh Cohen et al. (2007) hubungan korelasi yang kuat terhasil antara pemboleh ubah penglibatan ibu bapa dan efikasi kendiri murid dalam membuat keputusan kerjaya. Ini juga bermakna tahap penglibatan ibu bapa dan tahap efikasi kendiri murid mempunyai perkaitan yang kuat. Tahap tinggi yang diperoleh menunjukkan semakin tinggi tahap penglibatan ibu bapa dari segi bantuan instrumental dan sokongan emosi, maka semakin tinggi juga tahap efikasi kendiri murid. Melihat kepada tahap penglibatan ibu bapa dan tahap efikasi kendiri yang dimiliki oleh pelajar, perkara ini menunjukkan terdapat hubungan yang kuat kepada pelajar menengah swasta dalam membuat keputusan kerjaya.

Jadual 7: Analisis Pekali Korelasi Bagi Hubungan di Antara Penglibatan Ibu Bapa Dan Efikasi Kendiri Membuat Keputusan Kerjaya Dalam Kalangan Pelajar Menengah Swasta

\begin{tabular}{llcc}
\hline & & Efikasi Kendiri \\
\hline Korelasi & Penglibatan & Pekali Korelasi & 0.682 \\
Pearson & Ibu Bapa & Sig. (2-Hujung) & 0.000 \\
& & $n$ & 306 \\
\hline
\end{tabular}

\section{Perbincangan Kajian}

Berdasarkan analisis deskriptif yang telah dijalankan dalam kajian ini menunjukkan bahawa tahap penglibatan ibu bapa dari aspek bantuan instrumental dan sokongan emosi terhadap murid dalam membuat keputusan kerjaya berada pada tahap tinggi. Nilai tertinggi berdasarkan pemboleh ubah ini adalah pernyataan "Ibu bapa saya menggalakkan saya mendapat gred yang baik." (M=4.307), manakala nilai min yang terendah adalah pernyataan "Ibu bapa saya memberitahu saya tentang keseronokan dalam bidang pekerjaan saya pada masa hadapan" ( $\mathrm{M}=3.235)$. Perkara ini menunjukkan kecenderungan penglibatan ibu bapa dalam bantuan instrumental, komunikasi dan perbincangan memberi impak yang positif terhadap murid dalam membuat keputusan. Dapatan kajian ini adalah konsisten dengan dapatan kajian Zulkifli (2011) dan Neuenschwander (2020) yang melaporkan bahawa tahap penglibatan ibu bapa dalam pemilihan kerjaya kalangan pelajar adalah tinggi. Lazimnya, menurut Tsai (2014) hubungan yang erat di antara ibu bapa dengan anak dianggap penting untuk membantu proses perkembangan murid walaupun pada peringkat umur ini, murid dikatakan lebih masa diluangkan dengan rakan-rakan berbanding ibu bapa. Ini kerana mereka masih kurang pengalaman, tidak matang dan memerlukan sokongan ibu bapa untuk menjadikan mereka lebih berdikari (Azizi, 2006). Sungguhpun, ibu bapa di sekolah menengah swasta kebanyakan bekerja namun mereka masih cenderung melibatkan diri terhadap murid dalam membuat keputusan kerjaya.

Melihat kepada tahap efikasi kendiri murid sekolah menengah swasta dalam membuat keputusan, nilai keseluruhan min skor berada pada tahap tinggi. Ini merupakan dapatan yang positif terhadap tahap efikasi kendiri yang dimiliki oleh murid di sekolah menengah swasta. Nilai tertinggi berdasarkan 
pemboleh ubah ini adalah pernyataan "Menentukan jenis gaya hidup yang diingini" $(\mathrm{M}=4.349)$, manakala nilai min yang terendah adalah pernyataan "Berinteraksi dengan orang yang bekerja dalam bidang kerjaya yang saya minati” $(\mathrm{M}=3.075)$. Ini jelas menunjukkan murid sekolah menengah swasta percaya dan yakin terhadap kemampuan dalam membuat keputusan kerjaya. Ini selari dengan dapatan kajian oleh Halim et al. (2020) di mana efikasi kendiri sangat mempengaruhi keupayaan pelajar dalam eksplorasi kerjaya. Begitu juga dengan dapatan kajian oleh Baglama dan Uzunboylu (2017) mendapati pelajar yang mempunyai tahap efikasi kendiri yang tinggi cenderung dalam membuat keputusan kerjaya. Di samping itu, dapatan kajian ini menyokong dapatan kajian oleh Zakaria et al. (2020) mendapati pelajar memerlukan tahap efikasi kendiri yang tinggi dalam pemilihan kerjaya. Kajian oleh Jemini (2019) juga menunjukkan semakin tinggi tahap efikasi kendiri pelajar, semakin tinggi keyakinan dalam membuat keputusan kerjaya berbanding kepada pelajar yang mempunyai tahap efikasi yang rendah. Justeru, pelajar dengan mempunyai efikasi kendiri yang tinggi yakin bahawa mereka boleh belajar dan melaksanakan tugas yang diberikan walaupun tugas tersebut sukar (Malik et al., 2019).

Kajian ini juga telah menunjukkan hubungan yang kuat di antara penglibatan ibu bapa terhadap efikasi kendiri dalam membuat keputusan kerjaya di kalangan murid sekolah menengah swasta. Dapatan kajian ini menyokong hasil kajian oleh Lee et al. (2019), Roshandel \& Hui (2018) dan Mat Yussof (2018) apabila mendapati peranan ibu bapa mempunyai perkaitan yang positif kepada efikasi kendiri pelajar dalam pemilihan bidang pekerjaan. Selain itu, kajian Tzu et.al (2020) juga mendapati penglibatan ibu bapa terhadap pemilihan kerjaya di kalangan pelajar sekolah menengah di China. Manakala dalam dapatan kajian oleh kajian Inoa (2017) menunjukkan ibu bapa mementingkan kesejahteraan emosi anak-anak mereka supaya mereka lebih yakin dengan pilihan kerjaya masa depan. Oleh demikian, penglibatan ibu bapa dari aspek bantuan instrumental dan sokongan emosi dapat meningkatkan tahap keyakinan dan perkembangan emosi yang positif kepada anak-anak. Apabila anak-anak mempunyai perkembangan yang positif mereka lebih cekal dan berkeyakinan dalam merancang kehidupan mereka.

Secara keseluruhannya, murid daripada sekolah swasta yang mempunyai faktor persekitaran yang baik lebih cenderung untuk menunjukkan minat yang lebih tinggi dalam pekerjaan, bergiat aktif dalam menerokai alam kerjaya dan melibatkan diri dalam kegiatan penerokaan kerjaya sistematik dan aktiviti kerjaya. Malah, ibu bapa lebih cenderung memberi maklumat kerjaya berdasarkan bidang profesion, pengalaman dan kejayaan mereka kepada anak-anak. Di samping itu, penyediaan sumber kewangan yang mencukupi bagi menggalakkan anak-anak dalam penerokaan kerjaya seperti menghadiri kursuskursus yang berkaitan dengan kerjaya masa depan. Dengan ini, murid-murid lebih bermotivasi dan mampu menetapkan jangkaan tahap pencapaian yang lebih tinggi untuk pekerjaan yang lebih berprestasi. Sebaliknya, murid daripada keluarga berstatus sosioekonomi yang lebih rendah sering menghadapi lebih banyak halangan dan mendapat kurang sokongan daripada keluarga dalam proses pembangunan kerjaya berbanding rakan-rakan berstatus sosioekonomi yang lebih tinggi (Metheny \& McWhirter, 2013).

\section{Kesimpulan}

Dapatan kajian ini menunjukkan terdapat hubungan yang positif dan kuat antara penglibatan ibu bapa dan efikasi kendiri dalam membuat keputusan kerjaya di kalangan pelajar menengah swasta. Daripada keputusan yang diperoleh, kajian ini telah menunjukkan murid di sekolah swasta yang terdiri daripada latar belakang status sosioekonomi yang tinggi mampu dan yakin dalam membuat keputusan kerjaya. Hal demikian faktor seperti sokongan ibu bapa dari segi emosi, kewangan, sumber maklumat kerjaya daripada pengalaman ibu bapa telah mewujudkan keyakinan diri tinggi dalam murid dalam membuat perancangan dan membuat keputusan. Justeru, dapatan kajian telah menunjukkan kepentingan kecenderungan penglibatan ibu bapa dalam perbincangan, berkomunikasi dan sokongan emosi kepada murid dalam membuat keputusan kerjaya.

Antara cadangan lanjutan yang boleh diberikan kepada pengkaji akan datang adalah kajian ini perlu dilakukan di sekolah menengah swasta di seluruh Malaysia supaya hasil kajian ini dapat digeneralisasikan secara menyeluruh. Selain itu, kajian ini boleh dilakukan untuk melihat perbezaan 
penglibatan ibu bapa dan tahap efikasi kendiri mengikut jantina. Ini adalah kerana, kemungkinan tahap efikasi kendiri pelajar menengah swasta mempunyai perbezaan dalam membuat keputusan kerjaya. Tambahan lagi, kajian ini juga boleh dilakukan dengan melihat pengaruh penglibatan ibu bapa mengikut perspektif ibu bapa di sekolah menengah swasta. Di samping itu, kajian ini juga boleh dilanjutkan dengan melihat lebih mendalam pengaruh faktor persekitaran terhadap keputusan kerjaya murid di antara sekolah menengah awam dan swasta.

Kesimpulannya, penemuan kajian ini diharapkan dapat memberi sedikit penjelasan dan berserta ilmu yang boleh digunakan sebagai bahan bacaan dan rujukan penyelidik-penyelidik yang berminat menerokai lebih banyak ilmu dalam sekolah-sekolah swasta. Di samping itu, kajian ini juga diharapkan dapat memberi pengetahuan kepada semua ibu bapa di mana untuk menghasilkan murid yang mampu membuat keputusan kerjaya yang baik, ibu bapa haruslah terus membina komunikasi, memberi sokongan dan pendedahan sumber maklumat kerjaya kepada anak-anak.

\section{Rujukan}

Abd Samad, Sharizan, Othman, M. K., \& Kasa, M. D. (2019). Pembangunan Kerangka Konseptual Kajian Aspirasi Kerjaya Pelajar Tvet Kolej Komuniti Di Malaysia (Designing Conceptual Framework For The Study Of Career Aspirations Of Tvet In Malaysian Community College). Malim: Jurnal Pengajian Umum Asia Tenggara (Sea Journal Of General Studies), 20.

Bandura, A. (1986). Social foundations of thought and action: A social cognitive theory. Englewood Cliffs, NJ: Prentice- Hall, Inc.

Betz, N. E., \& Luzzo, D. A. (1996). Career assessment and the career decision-making self-efficacy scale. Journal of career assessment, 4(4), 413-428.

Bullock - Yowell, E., Leavell, K. A., McConnell, A. E., Rushing, A. D., Andrews, L. M., Campbell, M., \& Osborne, L. K. (2014). Career decision - making intervention with unemployed adults: When good intentions are not effective. Journal of employment counseling, 51(1), 16-30.

Christian Schöber, Kerstin Schütte, Olaf Köller, Nele McElvany \& Miriam M. Gebauer. (2018).Reciprocal effects between self-efficacy and achievement in mathematics and reading. Science Direct, 63,1-11.

Fabio, A. D., Palazzeschi, L., Asulin-Peretz, L., \& Gati, I. (2013). Career indecision versus indecisiveness: Associations with personality traits and emotional intelligence. Journal of Career Assessment, 21(1), 42-56.

Hui, K., \& Lent, R. W. (2018). The roles of family, culture, and social cognitive variables in the career interests and goals of Asian American college students. Journal of counseling psychology, 65(1), 98.

Hamzah, K. F., \& Subari, K. (2003). Faktor-faktor Yang Mempengaruhi Pemilihan Kerjaya Di Kalangan Remaja Melayu Di Daerah Batu Pahat (Doctoral dissertation, Universiti Teknologi Malaysia).

Jakaria, N. A., Mazlan, M., Samri, N., \& Shafie, S. N. A. (2020). Perbezaan Efikasi Kendiri Terhadap Pembangunan Kerjaya Berdasarkan Faktor Demografi. Jurnal Ulwan, 5(1), 223-235.

Jemini-Gashi, L., Duraku, Z. H., \& Kelmendi, K. (2019). Associations between social support, career self-efficacy, and career indecision among youth. Current Psychology, 1-7.

Krejcie \& Morgan. (1970). Menguasai penyelidikan dalam pendidikan: teori analisis \& interpretasi data. PTS Professional.

Lee Rodgers, J., \& Nicewander, W. A. (1988). Thirteen ways to look at the correlation coefficient. The American Statistician, 42(1), 59-66.

Mahmud, M. I. Information Processing Terhadap Ketidakfungsian Pemikiran Kerjaya Dan Efikasi Kendiri Kerjaya Pelajar Di Sebuah Universiti Awam.

Mat Yusoff, S. A. (2018). Pengaruh sokongan ibu bapa, personaliti dan motivasi ke atas efikasi kendiri membuat keputusan kerjaya (Doctoral dissertation, Universiti Pendidikan Sultan Idris).

Mohammad, N. H. (2017). Pengaruh kepercayaan efikasi kendiri terhadap tingkah laku

penerokaan kerjaya pelajar di sebuah sekolah menengah (Doctoral dissertation, Universiti Pendidikan Sultan Idris). 
Neuenschwander, M. P. (2020). Parental involvement and career decision-making: the case of Switzerland. Parental Involvement Across European Education Systems: Critical Perspectives, 133-148.

Schwarzer, R., \& Jerusalem, M. 1995. Generalized self-efficacy scale. Windsor, UK: Nfer-Nelson.

Oomen, A. (2016). Parental involvement in career education and guidance in secondary education. Journal of the National Institute for Career Education and Counselling, 37(1), 39-46.

Othman, N., Othman, N. H., Tin, P. B., Ismail, R., \& dan Pengurusan, F. E. (2012). Impak globalisasi dan tingkah laku pemilihan kerjaya keusahawanan dalam kalangan pelajar universiti. Prosiding Perkem, 7(1), 435-445.

Roshandel, J., Ghonsooly, B., \& Ghanizadeh, A. (2018). L2 Motivational Self-System and SelfEfficacy: A Quantitative Survey-Based Study. International Journal of Instruction, 11(1), 329344.

Salem, N. B. S., Ismail, F., Kadir, A. A., \& Salin, A. S. A. P. (2018). Hubungan Di Antara Pemilihan Kerjaya Dengan Kepuasan Kerjaya. Human Sustainability Procedia.

Te, T. S., Abdullah, A., \& Rashid, A. M. (2019). Pengaruh faktor terpilih terhadap aspirasi kerjaya keusahawanan dalam kalangan pelajar Kolej Komuniti (The Influence of Selected Factors toward Entrepreneurial Career Aspirations among Students of Community Colleges). Akademika, 89(3).

Ueno, S., \& Sekaran, U. (1992). The influence of culture on budget control practices in the USA and Japan: An empirical study. Journal of International Business Studies, 23(4), 659-674.

Workman, J. L. (2015). Parental influence on exploratory students' college choice, major, and career decision making. College Student Journal, 49(1), 23-30.

Zaib, Z. (2014). Pemilihan kerjaya pelajar Tingkatan 6 atas di sekolah menengah kluster di Kelantan (Doctoral dissertation, Universiti Tun Hussein Onn Malaysia).

Zainuddin, Z.A., \& Kutty, F. M. (2021). Hubungan Antara Efikasi Kendiri dan Motivasi Terhadap Pencapaian Akademik Pelajar Perempuan Jurusan STEM. Malaysian Journal of Social Sciences and Humanities (MJSSH), 6(3), 180-190.

Zakaria, N., Rubani, S. N. K., Ariffin, A., Hamzah, N., \& Nordin, N. S. (2020). Efikasi kendiri, Kemahiran Employabiliti dan Pemilihan Kerjaya dalam Kalangan Pelajar Kolej Vokasional. Online Journal for TVET Practitioners, 5(2), 71-76. 